\title{
Development of D-Loop mitochondrial markers for amplification of prey DNA from wolf scat
}

\author{
Hilke Schroeder ${ }^{1}$ D $\cdot$ Stefanie Palczewski ${ }^{1} \cdot$ Bernd Degen $^{1}$
}

Received: 6 April 2020 / Accepted: 14 September 2020 / Published online: 23 September 2020

(C) The Author(s) 2020

\begin{abstract}
Analysis of wolves dietary is a currently important theme because of the discussion about wolves preying on livestock as sheep or goats. We developed molecular markers to especially amplify the DNA of the prey out of wolf scat. For this purpose, we used the mitochondrial D-Loop using public available sequences for wolf and seven potential prey species (even-toed ungulates). We developed special primers amplifying either the wolves DNA or the prey DNA. In a fragment of 223-225 basepairs (bp) length we identified 21 SNPs, two 1-bp indels and one 3-bp indel, and three microsatellites to separate seven prey species from each other. Validation of the markers was performed by sequencing the PCR products of 12 fresh prey tissues and 20 wolf scat samples using the different primer pairs.
\end{abstract}

Keywords Wolf · Prey $\cdot$ Ungulates $\cdot$ Molecular markers $\cdot$ Mitochondrial DNA $\cdot$ D-Loop

Discussion about the diet of wolves (Canis lupus) grew louder the last decades due to recolonising of the European countries, especially about wolves preying on livestock instead of deer. In a review nearly 25 years ago, Meriggi and Lovari (1996) concluded that a simultaneous increase (or reintroduction) of wild ungulates may reduce predation on livestock. This was confirmed by other authors from different countries (Meriggi et al. 2011; Imbert et al. 2016; Newsome et al. 2016; Janeiro-Otero et al. 2020). In this discussion human management perspectives as economic interests and on the other hand protection obligations, of course, lead to conflicts as well as ideas for a co-existence between humans and wolves (Herzog 2018; Bruns et al. 2020; Martin et al. 2020). Thus, in order to alleviate this conflict between wolves recolonising former habitats and local human communities and to design concrete strategies, scientific research and analysis methods are needed to provide fundamental

Hilke Schroeder

hilke.schroeder@thuenen.de

Stefanie Palczewski

Stefanie.Palczewski@thuenen.de

Bernd Degen

Bernd.Degen@thuenen.de

1 Thuenen Institute of Forest Genetics, Sieker Landstrasse 2, Grosshansdorf 22927, Germany data on predator's diet (Meriggi et al. 2011; Newsome et al. 2016).

Molecular methods are useful in a wide range of scientific research. A lot of literature is available on the wolf about population ranges, migration, population dynamics and classification (e.g. Pilot et al. 2010; Duleba et al. 2015; Kraus et al. 2015; Ersmark et al. 2016; Hindrikson et al. 2017; Hulva et al. 2018). For prey species of wolves, molecular species identification methods from fresh material are available (Fajardo et al. 2006; Hoffmann et al. 2015). Molecular methods for the identification of prey species from scat are discussed since long (Symondson 2002). For the identification of prey species in wolf scat, e.g. species-specific short fragments are amplified using specific primers for each prey species (Shores et al. 2015). This helps to avoid amplifying only the wolf DNA from tissue cells of the wolf's digestive tract in the scat rather than the prey's DNA. Here, we describe different methods to extract the DNA from wolfs scat and the development of specific primer pairs to either amplify a range of potential prey species of the wolf (Capreolus capreolus, Cervus elaphus, Dama dama, Sus scrofa, Ovis aries, Capra hircus, Bos taurus) or the DNA of Canis lupus.

20 wolf scat samples were collected, 13 in a wolf enclosure in the Zoo Eberswalde (sample 1-13), six from a wild animal pack from a military training area "Heidehof" (sample 14-19) and one near the federal highway B96 (sample 
20), all in Brandenburg, Eastern Germany. As fresh reference material, we used 12 different fresh prey tissues from six species: $4 \times$ roe deer, $2 \times$ fallow deer, $1 \times$ red deer, $3 \times$ wild boar, $1 \times$ goat, and $1 \times$ sheep. Different DNA extraction methods were tested, (i) an ATMAB protocol by Dumolin et al. (1995), (ii) adding a phenol/chloroform step to this protocol, (iii) the QIAamp DNA Stool Kit, Qiagen (40724 Hilden, Germany) modified as follows: the homogenized samples were solved in $1.6 \mathrm{ml}$ extraction buffer and $0.5 \mu \mathrm{g} /$ $\mathrm{ml}$ Proteinase $\mathrm{K}$ was added, then incubated for $3 \mathrm{~h}$ at 50 ${ }^{\circ} \mathrm{C}$. Afterwards we followed the protocol as specified by the manufacturer, (iv) the InnuPREP Forensic Kit, Analytic Jena (07745 Jena, Germany). Best results were obtained using the modified Qiagen Stool Kit.

For marker development, at least 10 public available (NCBI) sequences for each prey species from different authors, in total 78 sequences, have been used for an alignment to identify differentiating variations between the prey species. We chose highly variable regions between wolf and the prey species to design primers that have no mismatches for all prey species and a high number of mismatches for the wolf sequence for amplifying the prey species and vice versa (Table 1).

In total in the 223-225 bp long mitochondrial D-Loop fragment 21 SNPs, two 1-bp indels and one 3-bp indel, and three microsatellites were identified based on 78 public available sequences. 18 out of the 21 SNPs are speciesspecific as well as all Indels (Table 2).

The in silico developed markers were first validated using 12 fresh prey tissues. After confirmation of the success of the markers with fresh material, the markers were applied to identify the prey species in the 20 wolf scat samples. In samples 1-13 either roe deer (one time), goat or cattle was found. For two samples amplification failed. The owner of the zoo confirmed that occasionally deer and mostly goat or cattle are fed to the wolves. Samples 14-20 contained either roe deer or red deer, which is the main game in the sampling area. Wolf DNA was only amplified and successfully sequenced when using the special D_Loop_wolf primers.

There is only a very small amount of literature about the use of molecular methods for the identification of prey species using scat (Monterroso et al. 2019). Especially for the molecular identification of the prey species of wolves, the assortment is even smaller. Thus, the fast and cost-efficient method described here will help to identify whether wolves prey on livestock or deer.
Table 1 Specifications of primers for amplification of a D-Loop fragment either from prey species or wolf

\begin{tabular}{llll}
\hline Primer name & sequence & Annealing temp. & Fragment length \\
\hline D_Loop_prey_F & GAT CCC TCT TCT CGC TCC GG & $55^{\circ} \mathrm{C}$ & $223-225$ bp \\
D_Loop_prey_R & GCT GAG TCC AAG CAT CCC C & $55^{\circ} \mathrm{C}$ & \\
D_Loop_wolf_F & TGT CCC TCT TCT CGC TCC GG & $55^{\circ} \mathrm{C}$ & $232 \mathrm{bp}$ \\
D_Loop_wolf_R & TGA GTG ATA GCA GAT TCC CC & $55^{\circ} \mathrm{C}$ & \\
\hline
\end{tabular}


Table 2 Prey species identifying DNA variations

\begin{tabular}{|c|c|c|c|c|c|c|c|}
\hline SNP* & $\mathrm{Cc}$ & $\mathrm{Dd}$ & $\mathrm{Ce}$ & Ss & $\mathrm{Oa}$ & $\mathrm{Ch}$ & $\mathrm{Bt}$ \\
\hline 389 & $\mathrm{C}$ & $\mathrm{T}$ & $\mathrm{T}$ & $\mathrm{C}$ & $\mathrm{T}$ & $\mathrm{C}$ & $\mathrm{C}$ \\
\hline 398 & A & A & A & $\mathrm{T}$ & A & $\mathrm{A} / \mathrm{C}$ & $\mathrm{C}$ \\
\hline 399 & G & G & G & $\mathrm{T}$ & A & G & G \\
\hline 404 & $\mathrm{~T}$ & $\mathrm{~T}$ & $\mathrm{~T}$ & $\mathrm{~T}$ & $\mathrm{~T}$ & $\mathrm{~T}$ & $\mathrm{C}$ \\
\hline 405 & $\mathrm{~T}$ & $\mathrm{~T}$ & $\mathrm{~T}$ & $:$ & $\mathrm{T}$ & $\mathrm{T}$ & $\mathrm{C}$ \\
\hline 406 & A & A & A & G & A & A & A \\
\hline 417 & $\mathrm{~T}$ & $\mathrm{~T}$ & $\mathrm{~T}$ & A & A & $\mathrm{T}$ & $\mathrm{C} / \mathrm{T}$ \\
\hline 421 & A & A & A & G & G & A & G \\
\hline 434 & $\mathrm{~T}$ & $\mathrm{~T}$ & $\mathrm{~T}$ & A & $\mathrm{T}$ & $\mathrm{T}$ & $\mathrm{T}$ \\
\hline 435 & $\mathrm{C}$ & $\mathrm{C}$ & $\mathrm{T}$ & $\mathrm{C}$ & $\mathrm{C}$ & $\mathrm{C}$ & $\mathrm{C}$ \\
\hline 458 & $\mathrm{~T}$ & $\mathrm{~T}$ & $\mathrm{~T}$ & $\mathrm{~T}$ & $\mathrm{~T}$ & $\mathrm{~T}$ & $\mathrm{C}$ \\
\hline 459 & $\mathrm{C}$ & $\mathrm{C}$ & $\mathrm{C}$ & $\mathrm{C}$ & $\mathrm{C}$ & $\mathrm{C}$ & G \\
\hline 461 & $\mathrm{C}$ & $\mathrm{C}$ & $\mathrm{C}$ & $\mathrm{C}$ & $\mathrm{C}$ & $\mathrm{C}$ & $\mathrm{T}$ \\
\hline 468 & $\mathrm{~T}$ & $\mathrm{~T}$ & $\mathrm{C}$ & $\mathrm{T}$ & $\mathrm{T}$ & $\mathrm{T}$ & $\mathrm{T}$ \\
\hline 471 & $\mathrm{C}$ & $\mathrm{C}$ & G & $\mathrm{C}$ & $\mathrm{C}$ & $\mathrm{C}$ & $\mathrm{C}$ \\
\hline 473 & $\mathrm{~T}$ & $\mathrm{~T} / \mathrm{C}$ & A & $\mathrm{C}$ & $\mathrm{T} / \mathrm{C}$ & $\mathrm{T}$ & $\mathrm{T}$ \\
\hline $476-478$ & TAA & TAA & $:::$ & TAA & TAA & TAA & TAA \\
\hline 519 & $\mathrm{~T}$ & $\mathrm{~T}$ & $\mathrm{~T}$ & $\mathrm{~T}$ & $\mathrm{C}$ & $\mathrm{T}$ & $\mathrm{T}$ \\
\hline 522 & $\mathrm{C}$ & $\mathrm{C}$ & $\mathrm{C}$ & $\mathrm{C}$ & $:$ & $\mathrm{C}$ & $\mathrm{C}$ \\
\hline 532 & $\mathrm{~T}$ & $\mathrm{~T}$ & $\mathrm{~T}$ & A & $\mathrm{T}$ & $\mathrm{T}$ & $\mathrm{T}$ \\
\hline 534 & G & G & G & $\mathrm{G}$ & G & $\mathrm{C}$ & $\mathrm{C}$ \\
\hline 536 & G & G & G & $\mathrm{T}$ & G & G & G \\
\hline 541 & A & A & A & A & G & A & A \\
\hline From 551 & $6 \times \mathrm{T}$ & $5 \times \mathrm{T}$ & $5 \times \mathrm{T}$ & $6 \mathrm{xT}$ & $6 \mathrm{xT}$ & $6 \mathrm{xT}$ & $7 \times T$ \\
\hline From 559 & $5 \times \mathrm{T}$ & $6 \mathrm{xT}$ & $5 \times \mathrm{T}$ & $5 \times \mathrm{T}$ & $5 \times \mathrm{x}$ & $4 \times \mathrm{T}$ & $4 \times T$ \\
\hline From 564 & $5 \times G$ & $5 \times \mathrm{xG}$ & $6 \mathrm{xG}$ & $4 \times G$ & $4 x G$ & $\mathrm{C}, 4 \times \mathrm{x}$ & $5 \times G$ \\
\hline
\end{tabular}

Cc Capreolus capreolus, Dd Dama dama, Ce Cervus elaphus, Ss Sus scrofa, Oa Ovis aries, Ch Capra hircus, Bt Bos taurus

*The numbering of nucleotide sites refers to a sequence of Capreolus capreolus (NCBI, accession No.: KP659204.1; bp 359 to 583)

Acknowledgements We are grateful to the colleagues from the Thuenen Institute of Forest Ecosystems in Eberswalde, especially Frank Tottewitz and the corresponding hunters for sampling of the wolf scats. And we thank all our hunting colleagues for providing us with fresh material from wild ungulates.

Funding Open Access funding enabled and organized by Projekt DEAL.

Open Access This article is licensed under a Creative Commons Attribution 4.0 International License, which permits use, sharing, adaptation, distribution and reproduction in any medium or format, as long as you give appropriate credit to the original author(s) and the source, provide a link to the Creative Commons licence, and indicate if changes were made. The images or other third party material in this article are included in the article's Creative Commons licence, unless indicated otherwise in a credit line to the material. If material is not included in the article's Creative Commons licence and your intended use is not permitted by statutory regulation or exceeds the permitted use, you will need to obtain permission directly from the copyright holder. To view a copy of this licence, visit http://creativecommons.org/licenses/by/4.0/.

\section{References}

Bruns A, Waltert M, Khorozyan I (2020) The effectiveness of livestock protection measures against wolves (Canis lupus) and implications for their co-existence with humans. Glob Ecol Conserv 21:e00868. https://doi.org/10.1016/j.gecco.2019.e00868

Duleba A, Skonieczna K, Bogdanowicz W, Malyarchuk B, Grzybowski $\mathrm{T}$ (2015) Complete mitochondrial genome database and standardized classification system for Canis lupus familiaris. Forensic Sci Int-Gen 19:123-129. https://doi.org/10.1016/j.fsigen.2015.06.014

Dumolin S, Demesure B, Petit RJ (1995) Inheritance of chloroplast and mitochondrial genomes in pedunculate oak investigated with an efficient PCR method. Theor Appl Genet 91: 1253-1256. https:// doi:https://doi.org/10.1007/BF00220937

Ersmark E, Klütsch CFC, Chan YL, Sinding M-H S, Fain SR, illarionova NA et al. (2016) From the past to the present: Wolf 
phylogeography and demographic history based on the mitochondrial control region. Front Ecol Evol 4:article 134. https:// doi:https://doi.org/10.3389/fevo.2016.00134

Fajardo V, González I, López-Calleja I, Martín I, Hernández PE, García T, Martín R (2006) PCR-RFLP authentication of meats from Red Deer (Cervus elaphus), Fallow Deer (Dama dama), Roe Deer (Capreolus capreolus), Cattle (Bos taurus), Sheep (Ovis aries), and Goat (Capra hircus). J Agr Food Chem 54:1144-1150. https://doi.org/10.1021/jf051766r

Herzog S (2018) Return of grey wolf (Canis lupus) to Central Europe: challenges and recommendations for future management in cultural landscapes. Ann For Res 61(2):203-209. https://doi. org/10.15287/afr.2018.1190

Hindrikson M, Remm J, Pilot M, Godinho R, Stronen AV, Baltrūnaité L et al (2017) Wolf population genetics in Europe: a systematic review, meta-analysis and suggestions for conservation and management. Biol Rev 92:1601-1629. https://doi.org/10.1111/ brv. 12298

Hoffmann GS, Johannesen J, Griebeler EM (2015) Species crossamplification, identification and genetic variation of 17 species of deer (Cervidae) with microsatellite and mitochondrial DNA from antlers. Mol Biol Rep 42:1059-1067. https://doi.org/10.1007/ s11033-014-3845-7

Hulva $\mathrm{P}$, Bolfíková $\mathrm{BC}$, Woznicová $\mathrm{V}$, Jindřichová $\mathrm{M}$, Benešová $\mathrm{M}$, Mysłajek RW et al (2018) Wolves at the crossroad: fission-fusion range biogeography in the western carpathians and central europe. Divers Distrib 24:179-192. https://doi.org/10.1111/ddi.12676

Imbert C, Caniglia R, Fabbri E, Milanesi P, Randi E, Serafini M, Tiorretta E, Meriggi A (2016) Why do wolves eat livestock? Factors influencing wolf diet in northern Italy. Biol Conserv 195:156-168. https://doi.org/10.1016/j.biocon.2016.01.003

Janeiro-Otero A, Newsome TM, van Eeden LM, Ripple WJ, Dormann CF (2020) Grey wolf (Canis lupus) predation on livestock in relation to prey availability. Biol Conserv 243:108433. https ://doi.org/10.1016/j.biocon.2020.108433

Kraus RHS, von Holdt B, Cocchiararo B, Harms V, Bayer H, Kühn R, Förster DW, Fickel J, Roos C, Nowak C (2015) A single-nucleotide polymorphism-based approach for rapid and cost-effective genetic wolf monitoring in Europe based on noninvasively collected samples. Mol Ecol Resour 15(2):295-305. https:// doi.org/10.1111/1755-0998.12307

Martin JL, Chamaillé-Jammes S, Waller DM (2020) Deer, wolves, and people: costs, benefits and challenges of living together. Biol Rev 95(3):782-801. https://doi.org/10.1111/brv.12587

Meriggi A, Brangi A, Schenone L, Signorelli D, Milanesi P (2011) Changes of wolf (Canis lupus) deit in Italy in relation to the increase of wild ungulate abundance. Ethol Ecol Evol 23(3):195-210. https://doi.org/10.1080/03949370.2011.577814

Meriggi A, Lovari S (1996) A review of wolf predation in Southern Europe: does the wolf prefer wild prey to livestock? J Appl Ecol 33(6):1561-1571. https://doi.org/10.2307/2404794

Monterroso P, Godinho R, Oliveira T, Ferreras P, Kelly MJ, Morin DJ, Waits LP, Alves PC, Mills LS (2019) Feeding ecological knowledge: the underutilised power of faecal DNA approaches for carnivore diet analysis. Mammal Rev 49:97-112. https://doi. org/10.1111/mam.12144

Newsome TM, Boitani L, Chapron G, Ciucci P, Dickman CR, Dellinger JA et al (2016) Food habits of the world's grey wolves. Mammal Rev 46(4):255-269. https://doi.org/10.1111/ mam. 12067

Pilot M, Branicki W, Jędrzejewski W, Goszczyński J, Jędrzejewska B, Dykyy I, Shkvyrya M, Tsingarska E (2010) Phylogeography history of grey wolves in Europe. BMC Evol Biol 10:104. https ://doi.org/10.1186/1471-2148-10-104

Shores C, Mondol S, Wasser SK (2015) Comparison of DNA and hair-based approaches to dietary analysis of freeranging wolves (Canis lupus). Conserv Genet Resour 7:871-878. https://doi. org/10.1007/s12686-015-0504-9

Symondson WOC (2002) Molecular identification of prey in predator diets. Mol Ecol 11:627-641. https://doi.org/10.1046/j.1365294x.2002.01471.x

Publisher's Note Springer Nature remains neutral with regard to jurisdictional claims in published maps and institutional affiliations. 